\title{
PENGARUH PROMOSI KESEHATAN DENGAN METODE CERAMAH DAN METODE CERAMAH DENGAN MEDIA VIDEO TERHADAP PERILAKU IBU HAMIL TENTANG PERSALINAN AMAN DI WILAYAH KERJA PUSKESMAS BATUNADUA PADANGSIDEMPUAN TAHUN 2015
}

\author{
Restu Yuliani ${ }^{1}$, Evawany Y Aritonang ${ }^{2}$, Syarifah $^{2}$ \\ ${ }^{1}$ Alumni Program Pascasarjana IKM FKM-USU, Medan \\ ${ }^{2}$ Staf Pengajar IKM FKM-USU, Medan
}

\begin{abstract}
Health promotion is basically a process of communication and behavior change process through health education. Health promotion activities can achieve maximum results, if the methods and media health promotion is of great concern and must be adapted to the target. The type of research was a quasi experimental (quasi experimental) with a pretest-posttest design, The population in this study, all pregnant women are entering the third trimester gestational age 37-39 weeks, in the region of 40 health centers Padangsidempuan Batunadua pregnant women. Samples numbered 40 pregnant women are 20 pregnant women group lecture and 20 pregnant women media group lecture with video media. The data were analyzed by using univariat and bivariat analysis with paired sample t-test pairs. The results showed that there are significant health promotion with a lecture and lecture with video media to change knowledge and attitudes of pregnant women on safe childbirth and health promotion methods most influential in improving knowledge, attitudes and actions of pregnant women in conducting safe childbirth in the work area Padangsidempuan Batunadua health centers is a lecture with video media. Need to improve knowledge and attitudes about safe childbirth so as to provide encouragement and support to pregnant women who give birth safely, health workers Batunadua Health Center suggested to use a lecture with video media in delivering health promotion to pregnant mothers because of a lecture with video media can portray a moving object together with natural sounds or sound accordingly.
\end{abstract}

Keywords : Health Promotion, Knowledge, Attitude, Action and Safe Childbirth

\section{PENDAHULUAN}

Angka kematian dijadikan sebagai salah satu indikator keberhasilan sistem pelayanan kesehatan suatu negara. Angka kematian ibu (AKI) adalah indikator di bidang kesehatan obstetri. Sampai saat ini angka kematian ibu di Indonesia masih relatif tinggi dibandingkan dengan negara-negara tetangga. Laporan survey demografi kesehatan Indonesia (SDKI) terakhir memperkirakan angka kematian ibu adalah 228 per 100.000 kelahiran hidup pada tahun 2007. Bahkan WHO, UNICEF, UNFPA, dan World Bank memperkirakan angka kematian ibu lebih tinggi, yaitu 420 per 100.000 kelahiran hidup. (Prasetyawati, A.E., 2012).

Menurut Dale (dalam Notoatmodjo, 2003), promosi kesehatan pada dasarnya merupakan proses komunikasi dan proses perubahan perilaku melalui pendidikan kesehatan. Kegiatan promosi kesehatan dapat mencapai hasil yang maksimal, apabila metode dan media promosi kesehatan mendapat perhatian yang besar dan harus disesuaikan dengan sasaran.
Media promosi kesehatan seperti metode ceramah mempunyai hubungan yang bermakna dalam peningkatan pengetahuan dan sikap masyarakat. Begitu juga dengan berbagai media promosi lainya memperlihatkan bahwa penggunaan media leaflet, audiovisual dapat dikombinasikan dengan diskusi kelompok cukup berpengaruh untuk meningkatkan pengetahuan dan sikap masyarakat (Sriyono, 2001).

Media audio visual adalah pemutaran film atau video. Media audio visual juga memiliki kelebihan. Kelebihan audio visual, antara lain : tidak membosankan penerima pesan, perpaduan antara suara dan visualisasi sehingga tidak monoton, pesan yang disampaikan dapat mudah dimengerti dan dipahami, karena melibatkan dua indera secara bersmaan (Barata, 2003).

Puskesmas Batunadua Padangsidempuan terdiri dari 13 kelurahan, 2 Desa. Pada tahun 2012 terdapat 2 kematian bayi dari 434 kelahiran, dan jumlah kematian ibu nol, penanganan komplikasi kebidanan 38 dari 434 ibu bersalin. Pada tahun 2013 jumlah kematian bayi sebanyak 3 bayi dan jumlah kematian ibu nol, penanganan komplikasi kebidanan 46 dari 450 dari ibu bersalin. 
Sedangkan pada tahun 2014 mengalami peningkatan kematian bayi, terdapat 8 kematian bayi dan 1 kematian ibu dan komplikasi kebidanan 47 dari 447 ibu bersalin (Puskesmas Batunadua, 2014). Survey awal peneliti, melakukan pengamatan di wilayah kerja puskesmas Batunadua Padangsidempuan. Penulis mewawancarai 15 orang ibu hamil di wilayah kerja puskesmas Batunadua Padangsidempuan, bahwa pengetahuan dan sikap ibu hamil tentang persalinan aman masih rendah. Hasil wawancara dengan 15 orang ibu hamil, mengatakan bahwa hampir semua persalinan diwilayah kerja Puskesmas Batunadua dilakukan di rumah, dengan berbagai alasan seperti biaya persalinan di rumah lebih murah, takut terhadap intervensi medis, karena dukungan suami/keluarga, kurangnya pengetahuan, riwayat persalinan sebelumnya dan alasan lainnya.

Selama ini penyuluhan promosi kesehatan yang dilakukan dengan menggunakan metode ceramah, oleh petugas kesehatan yang ada di puskesmas Batunadua Padangsidempuan. Hal ini dilakukan secara bersama-sama dengan program yang lain, namun tingkat pengetahuan sikap dan tindakan ibu hamil masih rendah.

Permasalahan penelitian adalah bagaimana pengaruh promosi kesehatan dengan metode ceramah dan metode ceramah dengan media video terhadap perilaku ibu hamil tentang persalinan aman di wilayah kerja Puskesmas Batunadua Padangsidempuan tahun 2015.

Tujuan penelitian ini adalah untuk menganalisis pengaruh promosi kesehatan dengan metode ceramah dan metode ceramah dengan media video terhadap perilaku ibu hamil tentang persalinan aman di wilayah kerja Puskesmas Batunadua Padangsidempuan tahun 2015.

\section{METODE PENELITIAN}

Jenis penelitian yang digunakan adalah eksperimen semu (quasi experiment) dengan rancangan pretest-posttest design. Penelitian ini menggunakan perlakuan promosi kesehatan dengan metode ceramah dan media video terhadap pengetahuan dan sikap ibu hamil tentang persalinan aman.

Penelitian ini dilakukan di wilayah kerja Puskesmas Batunadua Padangsidempuan. Penelitian ini dimulai bulan Januari 2015 sampai Juni 2015.

Populasi dalam penelitian ini, seluruh ibu hamil trimester ketiga yang memasuki usia kehamilan 37-39 minggu, di wilayah kerja puskesmas Batunadua Padangsidempuan sebanyak 40 orang ibu hamil. Jumlah sampel yang digunakan adalah ibu hamil trimester ke III yang ada di wilayah kerja puskesmas Batunadua Padangsidempuan sebanyak 40 orang ibu hamil.

Analisis data diperoleh dengan menggunakan perhitungan uji statistik memakai bantuan program komputer.

1. Analisis univariat merupakan analisis yang menitik beratkan kepada penggambaran atau deskriptif data yang diperoleh. Menggambarkan distribusi frekuensi dari masing-masing variabel bebas dan variabel terikat.

2. Analisis Bivariat, ini untuk melihat peningkatan pengetahuan, sikap dan tindakan ibu hamil tentang persalinan aman pre test dan post test dilakukan perlakuan.

\section{HASIL DAN PEMBAHASAN}

\section{Perbandingan Pengetahuan Responden Sesudah Promosi Kesehatan dengan Metode Ceramah dan Metode Ceramah dengan Media Video}

Hasil penelitian dengan menggunakan uji Mann Whitney menunjukkan bahwa pengetahuan ibu hamil dalam melakukan persalinan aman sesudah pemberian promosi kesehatan dengan metode ceramah nilai mean rank adalah 15,78 dan metode ceramah dengan media nilai mean rank 25,23 dengan selisih nilai delta 9,45. Adapun nilai $p$ value $=0,01<0,05$ yang artinya bahwa ada perbedaan yang signifikan antara promosi kesehatan dengan metode ceramah dan metode ceramah dengan media video atau dengan kata lain promosi kesehatan metode ceramah dengan media video lebih berpengaruh dalam meningkatkan pengetahuan ibu hamil dalam melakukan persalinan aman dibandingkan promosi kesehatan dengan metode ceramah saja. Perbedaan pengetahuan responden sebelum dan sesudah promosi kesehatan dengan metode ceramah dan metode ceramah dengan media video dilihat pada Tabel 1.

Tabel 1. Perbandingan Pengetahuan Responden Sesudah Promosi Kesehatan dengan Metode Ceramah dan Metode Ceramah dengan Media Video

\begin{tabular}{ccccc}
\hline $\begin{array}{c}\text { Pengetahuan } \\
\begin{array}{c}\text { Sesudah Promosi } \\
\text { Kesehatan }\end{array} \\
\text { Menurut Metode }\end{array}$ & $\begin{array}{c}\text { Mean } \\
\text { Rank }\end{array}$ & $\begin{array}{c}\text { Nilai } \\
\triangle\end{array}$ & $\boldsymbol{p}$ Value & $\mathbf{n}$ \\
\hline Ceramah & 15,78 & 9,45 & 0,01 & 20 \\
Ceramah-Video & 25,23 & & & \\
\hline
\end{tabular}

Berdasarkan hasil penelitian diketahui bahwa semua item pertanyaan pengetahuan mengalami peningkatan, dimana sebelum promosi kesehatan sebagian besar pengetahuan responden pada kategori kurang. Sebelum diberikan promosi kesehatan diketahui bahwa sebagian besar responden metode ceramah dan metode ceramah dengan media video menjawab salah pada pertanyaan di kuesioner. Hasil penelitian menunjukkan promosi kesehatan berpengaruh terhadap perubahan pengetahuan ibu hamil tentang persalinan aman. Hal ini bisa dilihat dari hasil pengukuran pengetahuan ibu hamil tentang persalinan aman sebelum diberikan promosi kesehatan pada kelompok metode ceramah yang berpengetahuan baik sebanyak 9 orang (45\%) sedangkan yang berpengetahuan kurang baik sebanyak 11 orang (55\%). Pada kelompok metode ceramah dengan media video yang berpengetahuan baik sebanyak 8 orang (40\%) sedangkan yang berpengetahuan kurang baik sebanyak 12 orang $(60 \%)$. 
Pada hasil pengukuran pengetahuan ibu hamil sesudah pemberian promosi kesehatan pada kelompok metode ceramah maupun kelompok metode ceramah dengan media video secara keseluruhan menjadi lebih baik. Pada kelompok metode ceramah 14 orang $(70 \%)$ telah berada dalam kategori baik sedangkan 6 orang $(30 \%)$ dalam kondisi kurang baik. Adapun pada kelompok metode ceramah dengan media video 19 orang (95\%) berada dalam kategori baik sedangkan 1 orang $(5 \%)$ dalam kondisi kurang baik.

Hasil penelitian ini juga sejalan dengan penelitian Yenita (2011), tentang pemilihan tenaga penolong persalinan di wilayah kerja Puskesmas Desa Baru Pasaman Barat menunjukkan adanya hubungan yang bermakna antara tingkat pengetahuan ibu dengan pemilihan tenaga penolong persalinan.

Perbandingan Sikap Responden Sesudah Promosi Kesehatan dengan Metode Ceramah dan Metode Ceramah dengan Media Video

Hasil penelitian dengan menggunakan uji Mann Whitney menunjukkan bahwa sikap ibu hamil dalam melakukan persalinan aman sesudah promosi kesehatan dengan metode ceramah nilai mean rank adalah 14,90 dan metode ceramah dengan media video lebih besar mean rank nilainya yaitu 26,10 , dengan nilai selisih hasil nilai delta 111,2 dan nilai $p$ value $=0,002$. Hal ini berarti secara statistik ada perbedaan yang signifikan antara promosi kesehatan dengan metode ceramah dan metode ceramah dengan media video untuk meningkatkan sikap atau dapat dikatakan promosi kesehatan metode ceramah dengan media video lebih efektif dalam meningkatkan sikap ibu hamil dalam melakukan persalinan aman dibandingkan promosi kesehatan dengan metode ceramah yang dapat dilihat pada Tabel 2 .

Tabel 2. Perbandingan Sikap Responden Sesudah Promosi Kesehatan dengan Metode Ceramah dan Metode Ceramah dengan Media Video

\begin{tabular}{ccccc}
\hline $\begin{array}{c}\text { Sikap Sesudah } \\
\text { Promosi Kesehatan } \\
\text { Menurut Metode }\end{array}$ & $\begin{array}{c}\text { Mean } \\
\text { Rank }\end{array}$ & $\Delta^{\text {Nilai }}$ & $\boldsymbol{p}$ Value & $\mathbf{N}$ \\
\hline Ceramah & 14,90 & 11,2 & 0,002 & 20 \\
Ceramah-Video & 26,10 & & & \\
\hline
\end{tabular}

Hasil penelitian menunjukkan promosi kesehatan berpengaruh terhadap perubahan sikap ibu hamil tentang persalinan aman. Perubahan sikap dipengaruhi oleh faktor pengetahuan dan kepercayaan yang didapatkan dari hasil penginderaan, salah satunya didapatkan pada pendidikan dan proses belajar. Sama halnya dengan pengetahuan, sikap ibu hamil juga menunjukkan adanya perubahan. Hal ini bisa dilihat dari hasil pengukuran sikap ibu hamil tentang persalinan aman sebelum pemberian promosi kesehatan dengan menggunakan ceramah adalah seimbang yaitu sebesar 50\% baik dan 50\% kurang baik, sedangkan sikap ibu hamil tentang persalinan aman yang memperoleh promosi kesehatan metode ceramah dengan media video mempunyai sikap baik yaitu sebesar $55 \%$ dan kurang baik $45 \%$.
Pada hasil pengukuran sikap ibu hamil tentang persalinan aman sesudah diberikan promosi kesehatan pada kelompok metode ceramah mengalami perubahan menjadi bersikap lebih baik yaitu sebesar $80 \%$, sedangkan yang diberi promosi kesehatan pada kelompok metode ceramah dengan media video juga terjadi perubahan yaitu secara keseluruhan berada dalam kategori baik $100 \%$.

Sikap adalah respon tertutup seseorang terhadap stimulus atau objek tertentu, yang sudah melibatkan faktor pendapat dan emosi yang bersangkutan (senang-tidak senang, setuju-tidak setuju, baik-tidak baik, dan sebagainya) (Notoatmodjo, 2011).

\section{Perbandingan Tindakan Responden Sesudah Promosi Kesehatan dengan Metode Ceramah dan Metode Ceramah dengan Media Video}

Hasil penelitian dengan menggunakan uji Mann Whitney menunjukkan bahwa tindakan ibu hamil dalam melakukan persalinan aman sesudah promosi kesehatan dengan metode ceramah nilai mean rank adalah sebesar 17,50 sedangkan metode ceramah dengan media video lebih nilai mean rank besar nilainya yaitu 23,50 dengan nilai selisih hasil nilai delta adalah 6 dan nilai $p$ value $=$ $0,031<\alpha(0,05)$. Hal ini berarti secara statistik ada perbedaan yang signifikan antara promosi kesehatan dengan metode ceramah dan metode ceramah dengan media video untuk meningkatkan tindakan ibu hamil dalam melakukan persalinan aman atau dapat disimpulkan bahwa promosi kesehatan metode ceramah dengan video lebih efektif dalam meningkatkan tindakan ibu hamil dalam melakukan persalinan aman dibandingkan penyuluhan dengan metode ceramah yang dapat dilihat pada Tabel 3 .

Tabel 3. Perbandingan Tindakan Responden Sesudah Promosi Kesehatan dengan Metode Ceramah dan Metode Ceramah dengan Media Video

\begin{tabular}{ccccc}
\hline $\begin{array}{c}\text { Tindakan Sesudah } \\
\text { Promosi Kesehatan } \\
\text { Menurut Metode }\end{array}$ & $\begin{array}{c}\text { Mean } \\
\text { Rank }\end{array}$ & $\begin{array}{c}\text { Nilai } \\
\Delta\end{array}$ & $\boldsymbol{p}$ Value & $\mathbf{n}$ \\
\hline Ceramah & 17,50 & 6 & 0,031 & 20 \\
Ceramah - Video & 23,50 & & & \\
\hline
\end{tabular}

Hasil penelitian menunjukkan promosi kesehatan berpengaruh terhadap perubahan tindakan ibu hamil tentang persalinan aman . Hal ini bisa dilihat dari hasil pengukuran tindakan ibu hamil tentang persalinan aman sesudah pemberian promosi kesehatan. Kelompok yang diberi promosi kesehatan dengan ceramah, jumlah ibu hamil yang melakukan persalinan aman adalah sebesar 12 orang atau $60 \%$, sedangkan pada kelompok yang diberi promosi kesehatan metode ceramah dengan media video, jumlah ibu hamil yang melakukan persalinan aman sebanyak 18 orang atau $90 \%$.

Hal ini tidak terlepas dari perubahan pengetahuan dan sikap ibu hamil tentang persalinan aman sesudah mendapatkan promosi kesehatan. Sejalan dengan hasil penelitian Ariyani (2012) pengaruh pengetahuan dan sikap terhadap tindakan sangat berpengaruh. 


\section{KESIMPULAN}

1. Terdapat pengaruh promosi kesehatan dengan metode ceramah dan metode ceramah dengan media video terhadap perubahan pengetahuan ibu hamil tentang persalinan aman di wilayah kerja puskesmas Batunadua Padangsidempuan, dimana hal ini dapat dilihat dari peningkatan rata-rata skor sebelum promosi kesehatan dengan metode ceramah adalah 6,75 dan sesudahnya mengalami peningkatan menjadi 8,10 , sedangkan sebelum promosi kesehatan metode ceramah dengan media video adalah 6,85 dan sesudahnya meningkat menjadi 9,15. Dikarenakan rata-rata sikap sebelum dan sesudah diberi promosi kesehatan, kelompok metode ceramah dan kelompok metode ceramah dengan media video mengalami peningkatan maka semakin baik pengetahuan yang dimiliki oleh ibu hamil setelah diberi promosi kesehatan maka semakin meningkat pemahamannya tentang persalinan aman.

2. Terdapat pengaruh promosi kesehatan dengan metode ceramah dan metode ceramah dengan media video terhadap perubahan sikap ibu hamil tentang persalinan aman di wilayah kerja puskesmas Batunadua Padangsidempuan, dimana hal ini dapat dilihat dari peningkatan rata-rata skor sebelum diberikan promosi kesehatan dengan metode ceramah adalah 14,70 dan sesudahnya mengalami peningkatan menjadi 16,45 sedangkan sebelum promosi kesehatan metode ceramah dengan media video adalah 15,00 dan sesudahnya meningkat menjadi 18,10. Dikarenakan rata-rata sikap sebelum dan sesudah diberi promosi kesehatan, kelompok metode ceramah dan kelompok metode ceramah dengan media video mengalami peningkatan, maka semangkin baik sikap yang dimiliki oleh ibu hamil setelah diberi promosi kesehatan maka pemahaman tentang persalinan aman semakin meningkat.

3. Metode promosi kesehatan yang paling berpengaruh dalam meningkatkan pengetahuan, sikap dan tindakan ibu hamil dalam melakukan persalinan aman di wilayah kerja puskesmas Batunadua Padangsidempuan adalah metode ceramah dengan media video, dimana hal ini dapat dilihat dari hasil post test promosi kesehatan metode ceramah dengan media video terhadap perubahan pengetahuan $(9,15)$, sikap $(18,10)$ dan tindakan $(0,9)$ lebih besar nilainya dibandingkan dengan hasil post test promosi kesehatan dengan metode ceramah terhadap perubahan pengetahuan $(8,10)$, sikap $(16,45)$ dan tindakan $(0,6)$. Hal ini berarti promosi kesehatan metode ceramah dengan media video lebih efektif dibandingkan promosi kesehatan dengan metode ceramah dalam meningkatkan pengetahuan, sikap dan tindakan ibu hamil dalam melakukan persalinan aman

\section{SARAN}

1. Perlu meningkatkan pengetahuan dan sikap tentang persalinan aman sehingga mampu memberikan dorongan serta dukungan kepada ibu hamil yang akan melahirkan dengan aman

2. Bagi dinas Kesehatan setempat diharapkan agar memfokuskan pada program promosi kesehatan tentang persalinan aman kepada ibu hamil

3. Petugas kesehatan Puskesmas Batunadua disarankan menggunakan metode ceramah dengan media video dalam menyampaikan promosi kesehatan kepada ibu hamil karena metode ceramah dengan media video dapat menggambarkan suatu objek yang bergerak bersama-sama dengan suara alamiah atau suara yang sesuai.

4. Bagi peneliti lain perlu dilanjutkan penelitian selanjutnya dengan menggunakan teknik metode ceramah dengan media yang berbeda seperti bermain peran, leaflet, sandiwara yang dapat mengukur pengetahuan, sikap dan tindakan.

5. Perlu dilakukan promosi kesehatan kepada ibu hamil mengenai persalinan yang aman, pentingnya pertolongan persalinan oleh tenaga kesehatan seperti bidan,dokter, perawat untuk membuat pendekatan seperti adat istiadat, budaya setempat, sehingga masyarakat mudah untuk menerima dan memanfaatkan ilmu kesehatan dan fasilitas kesehatan.

6. Bagi ibu yang akan bersalin agar tetap menggunakan fasilitas persalinan yang memadai sebagai tempat untuk melahirkan, sehingga proses persalinan dapat berjalan dengan aman dan selamat.

7. Untuk masyarakat berpartisipasi mendukung pemanfaatan fasilitas persalinan yang memadai melalui kebijakan-kebijakan bersama dengan tenaga kesehatan yang ada, sehingga semua ibu hamil yang akan melahirkan dapat memanfaatkan fasilitas persalinan yang memadai dalam proses persalinannya.

\section{DAFTAR PUSTAKA}

Ariyani, N.W., Sundari, N.N dan Budiani, N.N. 2012. Pengaruh Pelaksanaan Kelas Antenatal Terhadap Perilaku Ibu Hamil. Jurnal Skala Husada, Vol.9 No.1, April 2012: 10-15.

Barata, A.A., 2003. Dasar-Dasar Pelayanan Prima. Jakarta: Elex Medika Komputindo.

Evistron, J. 2009."Faktor-faktor yang Mempengaruhi Keputusan Memilih Penolong Persalinan pada Ibu Hamil di Kecamatan Babul Rahmah Kabupaten Aceh Tenggara" (tesis) Universitas Sumatra Utara.

Fauziah, S. 2014, Determinan Pemilihan Jenis Penolong dan Tempat Persalinan di Daerah Perdesaan Kabupaten Toraja Utara, Fakultas Kesehatan Masyarakat : Universitas Hasanuddin. 
Prasetyawati, E.A., 2012, Kesehatan Ibu dan Anak (KIA) Dalam Millenium Development Goals (MDGs). Yogyakarta : Nuha Medika.

Puskesmas Batunadua, 2014. Profil Puskesmas Batanadua Tahun 2014.

Notoadmodjo, 2003. Pendidikan Kesehatan dan Ilmu Perilaku. Jakarta : Rineka Cipta.

2011. Promosi Kesehatan : Teori dan Aplikasi, Edisi Revisi 2010. Jakarta : Rineka Cipta.

Sarwono, Y.E., 2011, Analisis Permintaan Masyarakat akan Pusat Kesehatan Masyarakat (Puskesmas) di Kota Semarang, Skripsi, Universitas Diponegoro Semarang.
Sriyono, 2001, Pendidikan Kesehatan Melalui Metode Diskusi Kelompok DanCeramah Menggunakan Audio Visual Untuk Meningkatkan,Pengetahuan, Sikap, Dan Ketrampilan Kader Posyandu Dalam Menemukan Tersangka Tuberculosis Paru.Tesis Program Pascasarjana UGM, Yogyakarta

Yenita, Sri. 2011. Faktor Determinan Pemilihan Persalinan di Wilayah Kerja Puskesmas Desa Baru Kabupaten Pasaman Barat Tahun 2011. Tesis Program Pascasarjana UNAND. 